\title{
Molecular activity underlying working memory
}

\author{
Pramod K. Dash, ${ }^{1}$ Anthony N. Moore, Nobuhide Kobori, and Jason D. Runyan \\ The Vivian L. Smith Center for Neurologic Research, and Department of Neurobiology and Anatomy, The University of Texas \\ Medical School, Houston, Texas 77225, USA
}

\begin{abstract}
The prefrontal cortex is necessary for directing thought and planning action. Working memory, the active, transient maintenance of information in mind for subsequent monitoring and manipulation, lies at the core of many simple, as well as high-level, cognitive functions. Working memory has been shown to be compromised in a number of neurological and psychiatric conditions and may contribute to the behavioral and cognitive deficits associated with these disorders. It has been theorized that working memory depends upon reverberating circuits within the prefrontal cortex and other cortical areas. However, recent work indicates that intracellular signals and protein dephosphorylation are critical for working memory. The present article will review recent research into the involvement of the modulatory neurotransmitters and their receptors in working memory. The intracellular signaling pathways activated by these receptors and evidence that indicates a role for $\mathrm{G}_{\mathrm{q}}$-initiated PI-PLC and calcium-dependent protein phosphatase calcineurin activity in working memory will be discussed. Additionally, the negative influence of calcium- and cAMP-dependent protein kinase (i.e., calcium/calmodulin-dependent protein kinase II (CaMKII), calcium/diacylglycerol-activated protein kinase C (PKC), and cAMP-dependent protein kinase $A$ (PKA)) activities on working memory will be reviewed. The implications of these experimental findings on the observed inverted-U relationship between $D_{1}$ receptor stimulation and working memory, as well as age-associated working memory dysfunction, will be presented. Finally, we will discuss considerations for the development of clinical treatments for working memory disorders.
\end{abstract}

Working memory is the capacity to temporarily keep in mind information that is not currently present to the senses in order to monitor and manipulate this information for a particular purpose. Therefore, it is the ability to keep one's thought on information acquired in the past, in light of present demands, in order to plan one's actions to reach a future goal. An example of working memory is watching for traffic as one attempts to cross the street. As one turns to cross the street, one must keep in mind the position of the oncoming traffic, while monitoring and using this information to calculate the appropriate time to initiate the attempt. The relative position of the cars is the information that is being held for the period of seconds it takes to make the decision to walk or not. Crossing the street is the goal, or purpose, that requires one's thoughts to be direct and maintained on the traffic flow. Once the information is used, it is forgotten to minimize conflicts with subsequent decisions (Dudchenko 2004). The ability to integrate different information for planning and for goal-directed, purposeful action such as decision-making and problem-solving also requires working memory. For example, when a person is presented with a problem, a series of comparative evaluations must be done in order to determine the pros and cons for each potential solution. This requires the transient storage and subsequent manipulation of the relevant information so that a plan can be formulated for obtaining the desired goal. Additionally, working memory relies on several other cognitive operations including attention, selection, updating, and cognitive flexibility. Once a plan has been formulated, its execution also requires working memory in order to perform the constant monitoring and manipulation of new information required to ensure that the goal is achieved, especially in plans involving heuristic steps. Thus, working memory is crucial for the normal, everyday activities we engage in, including those requiring highlevel (or executive) cognitive functions.

\footnotetext{
${ }^{1}$ Corresponding author.
}

E-mail p.dash@uth.tmc.edu; fax (713) 500-0621.

Article is online at http://www.learnmem.org/cgi/doi/10.1101//m.558707.
Recent studies suggest that working memory may also be involved in the acquisition and recall of episodic memory (Baddeley 2001; Ranganath et al. 2005). For example, fMRI (functional magnetic resonance imaging) studies have shown a strong overlap between the prefrontal regions activated in response to a working memory task and declarative learning. Furthermore, transcranial stimulation of the dorsolateral prefrontal cortex (the structure responsible for working memory in humans) during episodic memory encoding results in significantly impaired performance in a word pair task (Sandrini et al. 2003). Although the mechanism by which working memory contributes to episodic memory formation is not known, it has been suggested that it may involve organization of the information to be memorized, rehearsal during intentional learning, and/or linking semantic attributes to the memory (Buckner et al. 2000; Lee et al. 2000; Takashima et al. 2006). Likewise, memory recall may require the temporary sequencing or organization of the stored information in order to recreate the memory. Therefore, as will be discussed below, several disorders characterized by impaired memory acquisition/recall are also associated with working memory deficits.

Recent work in a number of laboratories has used animal experiments to examine the neurotransmitters and receptors, and the intracellular signaling pathways they activate, that are involved in normal working memory function. The present review will discuss the recent information regarding the prefrontal biochemical activity underlying working memory, as well as its dysfunction in neurological diseases. Special emphasis will be placed on recent advances in research regarding the intracellular signaling within the prefrontal cortex necessary for working memory.

\section{The prefrontal cortex and working memory}

Since the earliest working memory experiments performed by Jacobsen in 1936 on monkeys with prefrontal lesions, it has been known that prefrontal activity is required for the performance of tasks in which information needs to be monitored and manipu- 
lated (Jacobsen 1936), but not tasks that require the simple maintenance of information over time. More recent brain-imaging studies in humans using positron-emission tomography (PET) and fMRI have shown increased blood flow within the human prefrontal cortex during the delay-period of working memory tasks (Jonides et al. 1993; Petrides et al. 1993; D'Esposito et al. 1995). The prefrontal regions most often associated with working memory are the mid-dorsolateral, the orbitofrontal, and the mesial frontal regions. Interestingly, which of these different prefrontal regions is involved in the directing and maintaining of thought appears to be based on the type of information and the goal.

Research using monkey and rat models has yielded much of our present knowledge regarding prefrontal activity, neurotransmission, and the intracellular signaling involved in working memory. Behavioral paradigms such as the delayed match-tosample and delayed nonmatch-to-sample tasks have been shown to test the capacity for working memory in animals and in humans. In the delayed match-to-sample task, subjects are shown a sample (e.g., an object) to remember. Following a brief presentation of the object, it is removed from the field of view. After a delay of a few seconds, two objects (the previously seen object and a novel object) are presented. The subject is required to correctly identify the previously seen sample in order to receive a reward. This and other working memory tasks require the subject (1) to attend to particular items in order to acquire specific information, (2) to hold this information for a period of seconds during the delay period, and (3) to use this information for the purpose of making a correct response. Neurophysiologic studies in monkeys in the 1970s and 80s revealed that working memory was linked to maintained or persistent neuronal activity in the prefrontal cortex during the delay period ("delay-period activity") of these working memory tasks. Specific neurons were observed to be active during the delay period, and that this activity terminated when the participant completed the task. These cells were first identified in the dorsolateral PFC (dlPFC) of monkeys performing delay match-to-sample tasks (Fuster and Alexander 1971; Kojima and Goldman-Rakic 1984), but have since been observed in other brain areas. For example, neuronal activity during the delay period has been recorded in the inferior temporal cortex (Miller et al. 1993). However, while delay-period activity in the dIPFC is maintained in the presence of distracters, delay-period cells in the inferior temporal cortex cease to fire when the subject is presented with a distracting stimulus. In addition to the inferior temporal cortex, neuronal activity during the delay period has also been observed in other structures including the auditory cortex, the medial geniculate body, the hippocampus, the posterior parietal cortex, and the somatosensory cortex (Watanabe and Niki 1985; Koch and Fuster 1989; Sakurai 1990; Zhou and Fuster 1997). While the role of delay-period cells in working memory has not been fully elucidated, it has been observed that $\sim 70 \%$ of delay-period activity recorded in an oculomotor delayed response task represented transient information storage (Funahashi et al. 1993).

\section{Catecholamines in working memory}

As is the case for most of the brain, the major excitatory neurotransmitter for the prefrontal cortex is glutamate and the major inhibitory neurotransmitter is GABA. While these neurotransmitters are necessary for prefrontal neuronal activity and are involved in the focal specificity of this activity, modulatory neurotransmission in the PFC has been shown to play a prominent role in working memory. Prefrontal dopamine neurotransmission, in particular, has been shown to be important for working memory in animals and in humans. The seminal work by Bro- zoski et al. first demonstrated the involvement of catecholamines (dopamine and norepinephrine) in working memory. In this study, it was observed that depletion of PFC catecholamines by direct injection of 6-hydroxy-dopamine (6OHDA) caused profound working memory impairments in monkeys (Brozoski et al. 1979). These impairments are comparable to those seen following lesion of the PFC, indicating the prominent role for catecholamines in working memory. Since this initial observation of the requirement of dopamine, a large body of research has examined the role of dopamine, and the role of specific dopamine receptor subtypes in working memory. For instance, depletion of PFC catecholamines has been shown to impair working memory in rats (Simon et al. 1979), whereas iontophoretic application of dopamine into the PFC has been observed to increase delay-period activity (number of spikes/sec) in monkeys performing working memory tasks (Sawaguchi 2001). Furthermore, it has recently been observed in rats and in humans that prefrontal dopamine levels transiently increase during working memory, reiterating the importance of this modulatory neurotransmitter for working memory (Phillips et al. 2004; Aalto et al. 2005).

While dopamine is required for normal working memory, subsequent studies have shown that excessive dopamine can cause working memory impairments. For example, infusion of high levels of dopamine $\mathrm{D}_{1}$ receptor agonists into the prefrontal cortex has been demonstrated to impair working memory (Zahrt et al. 1997; Runyan et al. 2005). Dose-response studies have revealed that working memory performance requires an optimal range of dopamine (or $\mathrm{D}_{1}$ receptor stimulation). These studies showed that prefrontal $\mathrm{D}_{1}$ receptor stimulation follows an inverted-U-shaped dose-response curve with both insufficient and excessive stimulation resulting in working memory impairments (Williams and Goldman-Rakic 1995; Arnsten and GoldmanRakic 1998; Runyan et al. 2005). Consistent with this, it has been demonstrated that the working memory deficits observed in conditions associated with elevated dopamine levels (e.g., stress) are reduced by administration of $\mathrm{D}_{1}$ receptor antagonists. Similarly, conditions associated with reduced dopamine levels (e.g., Parkinson's Disease) show benefit from the use of $\mathrm{D}_{1}$ agonists (or LDOPA, a brain-permeable precursor for dopamine) (Cools 2006). In addition to dopamine, this inverted-U-shaped response curve has been identified for norepinephrine, a catecholamine derived from dopamine.

\section{Receptors for modulatory neurotransmitters}

Dopamine receptors are generally divided into two families: $\mathrm{D}_{1}$ like $\left(\mathrm{D}_{1}, \mathrm{D}_{5}\right)$ and $\mathrm{D}_{2}$-like $\left(\mathrm{D}_{2}, \mathrm{D}_{3}\right.$, and $\left.\mathrm{D} 4\right)$ based upon their ability to either increase $\left(\mathrm{D}_{1}\right.$-like) or decrease $\left(\mathrm{D}_{2}\right.$-like) cAMP levels. The influence of dopamine on prefrontal neurons is mediated largely by $D_{1}$ receptors, which are more abundant than $D_{2}$ receptors in these cells (Lidow et al. 1991). For example, it has been shown that $\mathrm{D}_{1}$ antagonists (which also inhibit $\mathrm{D}_{5}$ receptors), but not $\mathrm{D}_{2}$ antagonists, suppress PFC delay-period activity and disrupt working memory in monkeys and in rats (Lidow et al. 1991; Sawaguchi and Goldman-Rakic 1991; Didriksen 1995; Aultman and Moghaddam 2001). Similarly, prefrontal infusion of low levels of $D_{1}$ agonists, but not $\mathrm{D}_{2}$ agonists, improves working memory (Arnsten et al. 1994; Runyan et al. 2005). Interestingly, $\mathrm{D}_{4}$ receptors, which are also abundantly expressed in the PFC (MeadorWoodruff et al. 1996), have been observed to be involved in working memory (Zhang et al. 2004).

$\mathrm{D}_{1}$ receptors are present in close conjunction with glutamatergic synapses on the distal dendritic spines of prefrontal neurons (Smiley and Goldman-Rakic 1993; Williams and GoldmanRakic 1993). By comparison, $D_{5}$ receptors, which have similar intracellular activities as $\mathrm{D}_{1}$, are largely extrasynaptic (Paspalas 
and Goldman-Rakic 2004). As most agonists/antagonists act on both $\mathrm{D}_{1}$ and $\mathrm{D}_{5}$ receptors, it is difficult to determine the contribution of each of these receptor subtypes to working memory. $\mathrm{D}_{1}$ receptors are expressed on both pyramidal neurons and on GABAergic interneurons (Muly et al. 1998) within the prefrontal cortex. Due to this distribution, dopamine has been shown to not only stimulate the activity of pyramidal neurons, but also to either enhance or depress (in a concentration-dependent manner) the excitability of fast-spiking (FS) inhibitory interneurons (Gao and Goldman-Rakic 2003). Since inhibitory neurons within the prefrontal cortex are thought to restrict the spatial extent of neuronal activity, the presence of $\mathrm{D}_{1}$ receptors on inhibitory neurons suggests that they play an important role in promoting focal, persistent excitability (Trantham-Davidson et al. 2004).

In addition to dopamine, research involving monkeys, rats, and humans has demonstrated that other modulatory neurotransmitters influence working memory such as norepinephrine acting through $\alpha$-adrenoreceptors (Arnsten and Goldman-Rakic 1985; Li and Mei 1994), serotonin through 5-HT ${ }_{2 \mathrm{~A}}$ receptors (Williams et al. 2002), and acetylcholine through muscarinic receptors (Granon et al. 1995) (Fig. 1). For example, it has been shown that moderate levels of norepinephrine that activate $\alpha_{2 \mathrm{~A}}$ adrenoreceptors resulted in improved working memory, whereas at higher levels, norepinephrine activates $\alpha_{1}$ receptors, resulting in impaired working memory (Franowicz and Arnsten 1998; Mao et al. 1999; Arnsten 2000). Similarly, it has been proposed that excessive prefrontal norepinephrine levels may contribute to the working memory deficits observed following stress or conditions such as attention deficit hyperactivity disorder (ADHD) and schizophrenia (Birnbaum et al. 1999; Friedman et al. 1999; Russell et al. 2000).

\section{Intracellular signaling activated by modulatory neurotransmitter receptors}

A number of biochemical and genetic studies have demonstrated that the receptors that are necessary for working memory (e.g., $\mathrm{D}_{1}$, muscarinic and $\alpha_{2 \mathrm{~A}}$ receptors) initiate intracellular second messenger pathways. Recent research has provided evidence that the activities of these intracellular signaling pathways are critical for working memory.

Both $\mathrm{D}_{1}$ and $\alpha_{2 \mathrm{~A}}$ receptors belong to a family of seven transmembrane-spanning receptors known as G-protein-coupled receptors (GPCRs). Upon neurotransmitter binding, conformational changes in these receptors allow them to interact with specific heteromeric GTP-binding proteins (G-proteins) in the cytoplasm. The major heteromeric G-proteins found in the prefrontal cortex are $G_{s}, G_{i}$, and, $G_{q}$, each having distinct effects on

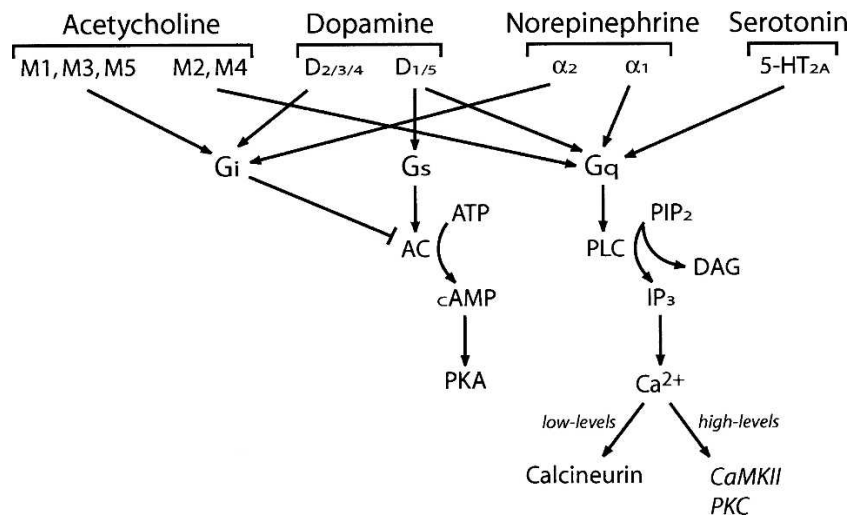

Figure 1. Diagram of selected modulatory neurotransmitters and their receptors that couple to either $\mathrm{G}_{\mathrm{i}}, \mathrm{G}_{\mathrm{s}}$, or $\mathrm{G}_{\mathrm{q}}$ receptors are shown. intracellular signaling. For example, the $G_{s}$ pathway enhances intracellular cAMP concentrations (via increased adenylyl cyclase activity), resulting in the activation of cAMP-dependent protein kinase A (PKA) and Epac (de Rooij et al. 1998). In contrast, $G_{i}$ proteins reduce cAMP levels and PKA activity. $G_{\mathrm{q}}$ proteins couple the plasma membrane receptor to phosphoinositol-phospholipase C (PI-PLC), causing increases in intracellular diacylglycerol and inositol trisphosphate $\left(\mathrm{IP}_{3}\right) . \mathrm{IP}_{3}$ causes the release of calcium $\left(\mathrm{Ca}^{2+}\right)$ from intracellular stores that can activate several calciumdependent enzymes including the phosphatase calcineurin, CaMKII, and PKC. Although the G-protein-coupled responses are specific, there can be cross-talk between these signaling cascades at multiple levels. For instance, increased intracellular calcium can increase cAMP levels by stimulating the activity of calciumsensitive adenylyl cyclase.

In terms of the G-proteins with which they interact, $\mathrm{D}_{1}$ receptors can be either $\mathrm{G}_{\mathrm{s}}$ or $\mathrm{G}_{\mathrm{q}}$ coupled, and upon dopamine binding can result in increased cAMP and/or calcium mobilization (Wang et al. 1995). Interestingly, the $\mathrm{D}_{1}$ agonist SKF83959 selectively stimulates PI-PLC activity, suggesting the specific activation of $G_{q}$-coupled $D_{1 / 5}$ receptors (Jin et al. 2003). Conversely, the $\mathrm{D}_{1}$ agonist SKF86284 stimulates adenylyl cyclase, an effect mediated by $G_{s}$ proteins, without having any effect on phosphoinositide hydrolysis (Undie et al. 1994). Although the reason for this selectivity is not well understood, these findings suggest that the $D_{1}$ receptors coupled to Gs proteins, and those coupled to $G_{\mathrm{q}}$ proteins, may represent distinct subpopulations of $D_{1}$ receptors. $D_{5}$ receptors in the prefrontal cortex have recently been observed to be in close proximity with $\mathrm{IP}_{3}$-gated calcium stores (i.e., subsurface cisterns and mitochondria) (Paspalas and Goldman-Rakic 2004). In addition to $D_{1 / 5}$ receptors, $\alpha_{1}$-adrenoreceptors, 5- $\mathrm{HT}_{2 \mathrm{~A}}$, and muscarinic cholinergic M1 receptors are also $\mathrm{G}_{\mathrm{q}}$ coupled and have been linked to calcium mobilization. In contrast, $\mathrm{D}_{2}$ and $\alpha_{2 \mathrm{~A}}$ receptors are $\mathrm{G}_{\mathrm{i}}$-coupled receptors and their stimulation results in decreased cAMP levels.

\section{$\mathrm{G}_{\mathrm{q}}$-activated signals in working memory}

Several lines of research have indirectly indicated that signaling via the $G_{q}$ pathway is involved in working memory. First, alterations in prefrontal $G_{\mathrm{q}}$ signaling have been associated with working memory deficits in schizophrenia patients (Lidow 2003). For example, it has been observed that the dlPFC of schizophrenics exhibits over twice the normal level of calcyon, while the protein regulator of $G$ protein signaling-4 (RGS4, an inhibitor of $G_{\mathrm{q}}$ protein-induced intracellular $\mathrm{Ca}^{2+}$ release), is down-regulated (Mirnics et al. 2001; Koh et al. 2003). Second, working memory impairments resulting from stress have been shown to result from overactivation of PKC (Birnbaum et al. 2004), which can be activated by $\mathrm{G}_{\mathrm{q}}$-induced increases in intracellular $\mathrm{Ca}^{2+}$. Third, it has recently been observed that persistent, recurrent excitation in prefrontal neurons requires calcium release from intracellular stores through the $\mathrm{IP}_{3}$ pathway in vitro (Gao and Goldman-Rakic 2006). Fourth, persistent activity of layer V pyramidal neurons in the entorhinal cortex is dependent on calcium-sensitive cation channels (Egorov et al. 2002).

Recent studies from the investigator's laboratory using a delay match-to-place working memory task have provided more direct biochemical evidence that the $G_{\mathrm{q}}$ pathway is necessary for working memory (Runyan et al. 2005). In this task, rats are allowed to find the location of a hidden platform in a water maze; then, after a brief delay, are required to find it once again. Following an intertrial interval (typically $4 \mathrm{~min}$ ), the location of the hidden escape platform is moved and the task is repeated (Fig. 2). The task trial is repeated at least five times per testing session. The decrease in time between the first (naive) and second (experienced) trial is used as an indicator of the animal's capacity for 


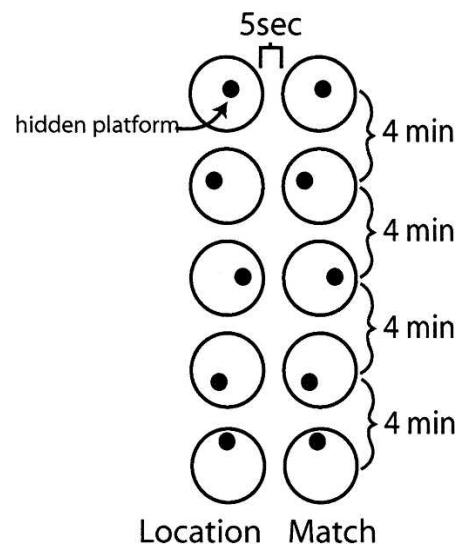

Figure 2. Schematic representation of the delayed match-to-place task. In the delayed match-to-place task, rats are required to search for and find a hidden platform within a circular tank of water (the location trial). After a delay of $5 \mathrm{sec}$, the animal is reintroduced into the tank and required to once again find the hidden platform (the match trial). The platform is moved, and after a 4-min intertrial interval, the rat is tested once again. This procedure is repeated at least five times per session. The difference in latency between the location and match trials is used as a measure of working memory.

working memory. Performance in this task is dependent on mPFC activity, as its inactivation by mucimol profoundly impairs performance. Similar to other working memory tasks, either too much or too little dopamine also impairs performance in this task (Williams and Goldman-Rakic 1995; Zahrt et al. 1997; Runyan et al. 2005). To assess a role for $G_{q}$ proteins in working memory, we measured its levels in membrane and cytosolic fractions from the medial prefrontal cortex (mPFC, the homolog of the prefrontal regions associated with working memory in the human and primate [Kolb 1984; Uylings and van Eden 1990]) tissue samples taken at different time points (in terms of seconds) following the location trial. Once activated, the $\alpha$ subunit of $\mathrm{G}_{\mathrm{q}}$ proteins translocate from the membrane to a cytosolic fraction (Arthur et al. 1999). Thus, a redistribution of these proteins can be used as an indicator of prior activation. Our findings show that $\mathrm{G}_{\mathrm{q}}$ translocates from the membrane during the delay period of the match-to-place task (Runyan et al. 2005), suggesting that the $G_{\mathrm{q}}$ signaling cascade is activated during working memory. Since activation of $\mathrm{G}_{\mathrm{q}}$ proteins leads to enhanced PI-PLC activity, the involvement of this enzyme was investigated using a pharmacological inhibitor of PLC. As anticipated, intra-mPFC infusion of U73122 resulted in working memory impairments.

\section{Protein kinases and working memory}

As stated above, the activation of $\mathrm{G}_{\mathrm{q}}$ proteins is linked to increases in intracellular calcium, principally through the PI-PLCmediated increase in IP3 and release of calcium from intracellular stores. Several calcium-sensitive enzymes, including CaMKII and PKC, are activated in response to elevated intracellular calcium. Our work using the delay match-to-place task has shown that working memory results in transient increases in the activities of CaMKII and PKC in the medial prefrontal cortex (Runyan et al. 2005). Using the CaMK inhibitor KN-92, it was found that inhibition of CaMKII in the prefrontal cortex is associated with improved performance in the working memory task. Similarly, intra-mPFC infusion of either the pan-specific PKC inhibitor GF109203X or the inhibitor of calcium-sensitive PKC isoforms Gö6976, also resulted in improved working memory. These findings suggest that $\mathrm{G}_{\mathrm{q}}$-mediated calcium-responsive kinase activity plays a negative role in working memory. Consistent with this suggestion, stress-associated working memory impairments have been shown to result from overactivation of PKC in the PFC (Birnbaum et al. 2004). It is thought that stress-associated enhanced PKC activity in the prefrontal cortex is due to engagement of $\alpha 1$ adrenergic receptors, a $G_{\mathrm{q}}$-coupled receptor. Blockade of this kinase activity improves working memory performance in stressed animals, suggesting that enhanced phosphorylation of substrate proteins may be detrimental for working memory.

\section{Protein phosphatases and working memory}

In addition to calcium-sensitive kinase activity, increases in intracellular calcium also activate the calcium-sensitive phosphatase calcineurin (at concentrations lower than that required for kinase activation). The abovementioned studies, performed both in normal animals and following pathological conditions, indicate that kinase activity plays a negative role in working memory, suggesting that substrate dephosphorylation may be required for proper working memory function. In support of this suggestion, genetic studies using forebrain-specific calcineurin knockout mice have demonstrated a requirement for this phosphatase in working memory (Zeng et al. 2001). However, the absence of calcineurin in several brain structures including the hippocampus of these mice makes assigning a specific role for calcineurin activity in working memory difficult. A recent study has provided biochemical evidence for prefrontal calcineurin activation in the delay match-to-place working memory task (Runyan et al. 2005). Consistent with its higher affinity for calcium, calcineurin was activated prior to the activation of calcium-dependent kinases. Furthermore, intra-mPFC inhibition of calcineurin activity resulted in a dose-dependent impairment in working memory performance. Taken together, these studies suggest that while calcineurin-mediated protein dephosphorylation is required for working memory, calcium-dependent phosphorylation is detrimental.

Based on these observations, calcineurin activity could participate in working memory in two ways. (1) Calcineurinmediated protein dephosphorylation is involved in modulating the ion channel currents necessary for delay-period activity within the prefrontal cortex. (2) Calcineurin activity is required for suppressing task-irrelevant prefrontal activity, thereby increasing the signal-to-noise ratio. This may provide a molecular mechanism for previous models of working memory in which a decrease in "noise" or irrelevant activity and an increase in "signal" or relevant activity has been theorized to be necessary for maintaining the information required for performing goaldirected action (Durstewitz et al. 2000; Gonzalez-Burgos et al. 2005). These possibilities are not meant to be exhaustive or exclusive. Thus, continued research directed at revealing the substrates (e.g., ion channels or receptors) that are modulated by calcium and/or calcineurin activity and the identification of the cell types (e.g., excitatory vs. inhibitory), in which calcineurin activity is enhanced, is needed to further elucidate how protein dephosphorylation contributes to working memory.

\section{Potential substrates contributing to working memory}

Working memory is likely to involve transient modulation of activity of substrate proteins. Since ion channel and cell-surface receptors significantly contribute to neuronal excitability, their transient dephosphorylation may be critical for delay cell activity and working memory. Many channels and receptors phosphorylated by calcium-dependent kinases CaMKII and PKC can be dephosphorylated by calcineurin. For example, phosphorylation of $\mathrm{K}_{\mathrm{v}} 1.4 \mathrm{~K}^{+}$channels by CaMKII leads to slow inactivation of these channels. On the other hand, dephosphorylation of the same $\mathrm{K}^{+}$ channel by calcineurin leads to its fast inactivation (Roeper et al. 
Table 1. A list of substrates whose activities are known to be altered by phosphorylation/dephosphorylation that may participate in working memory

\begin{tabular}{|c|c|c|}
\hline Enzymes & Action on receptors, ion channels, and currents & References \\
\hline PKA & $\begin{array}{l}\text { Suppresses rapidly inactivating } \mathrm{Na}^{+} \text {channels; suppresses slowly inactivating } \mathrm{K}^{+} \\
\text {currents; potentiation of L-type } \mathrm{Ca}^{2+} \text { channel; increases } \mathrm{N} \& \mathrm{P} / \mathrm{Q} \\
\text { channel-mediated calcium rise; increases NMDAr calcium influx }\end{array}$ & $\begin{array}{l}\text { Solem et al. 1997; Maurice et al. 2001; Dong and } \\
\text { White 2003; Young and Yang 2004; Skeberdis } \\
\text { et al. } 2006\end{array}$ \\
\hline PKC & $\begin{array}{l}\text { Slows inactivation of persistent } \mathrm{Na}^{+} \text {channels }[\mathrm{I}(\mathrm{NaP})] \text {; suppression of L-type } \mathrm{Ca}^{2+} \\
\text { channels; increases steady-state NMDA currents }\end{array}$ & $\begin{array}{l}\text { Gorelova and Yang 2000; Chen et al. 2004; } \\
\text { Young and Yang 2004 }\end{array}$ \\
\hline CaMKII & Slows inactivation of $\mathrm{K}_{\mathrm{v}} 1.4 \mathrm{~K}^{+}$channels; increases kainate-induced ion current & McGlade-McCulloh et al. 1993; Roeper et al. 1997 \\
\hline Calcineurin & $\begin{array}{l}\text { Fast inactivation of } \mathrm{K}_{\mathrm{v}} 1.4 \mathrm{~K}^{+} \text {channels; inhibition of L-type } \mathrm{Ca}^{2+} \text { current; } \\
\text { potentiation of mGluR5 }\end{array}$ & $\begin{array}{l}\text { Roeper et al. 1997; Day et al. 2002; Alagarsamy et } \\
\text { al. } 2005\end{array}$ \\
\hline
\end{tabular}

1997). The activity of L-type $\mathrm{Ca}^{2+}$ channels in the hippocampus is enhanced via dephosphorylation by calcineurin (Norris et al. 2002), and the voltage-dependent Kv2.1 K(+) channel, when dephosphorylated by calcineurin, translocates from a clustered to a more uniform distribution (Misonou et al. 2004). Additionally, there is recent evidence that suggests that $\mathrm{D}_{1}$ receptors are physically linked with calcineurin, and that calcineurin actively dephosphorylates $\mathrm{D}_{1}$ receptors (Adlersberg et al. 2004). A list of several channels and receptors whose activity is modulated by phosphorylation/dephosphorylation is provided in Table 1 .

Although the substrates that are dephosphorylated in vivo have not been identified, in vitro neurophysiologic studies have demonstrated that $D_{1}$ receptor activity can modulate the function of several ion channels and receptors. For example, $\mathrm{D}_{1}$ stimulation can increase the excitability of prefrontal pyramidal neurons through inhibition of several $\mathrm{K}^{+}$currents (Dong and White 2003). In addition, $\mathrm{D}_{1}$ receptor stimulation in prefrontal neurons has also been reported to modulate a persistent sodium current $\left(\mathrm{I}_{\mathrm{Nap}}\right)$ that is dependent on PKC, but not PKA, activity (Gorelova and Yang 2000). Prefrontal $D_{1}$ receptor suppression of L-type $\mathrm{Ca}^{2+}$ currents has also been shown to require $\mathrm{Ca}^{2+}$ dependent molecular activity (Young and Yang 2004). Similarly, the excitability of prefrontal neurons has been observed to increase as a result of interaction between $\mathrm{D}_{1}$ and NMDA receptors, and this interaction requires $\mathrm{Ca}^{2+}$-dependent signaling (Wang and O'Donnell 2001). In addition to direct influences on excitatory neurons, modulation of ion channels and receptors in inhibitory neurons can also influence working memory (Rao et al. 2000). Concomitant with this, it has been reported that $D_{1}$ receptor stimulation increases the activity of fast-spiking interneurons through the modulation of potassium currents (Gorelova et al. 2002)

In addition to D1 receptors, 5- $\mathrm{HT}_{2}$ receptors (which are also involved in working memory) have been shown to inhibit L-type $\mathrm{Ca}^{2+}$ currents in prefrontal pyramidal neurons. This occurs as a result of phospholipase $\mathrm{C}$ activation, mobilization of intracellular calcium, and the activation of calcineurin (Day et al. 2002). Recently, it has been demonstrated that stimulation of prefrontal $\alpha 2 \mathrm{a}$ receptors improves working memory performance by reducing cAMP and closure of hyperpolarization-activated cyclic nucleotide-gated (HCN) channels (Wang et al. 2007).

\section{Inverted-U response curve and calcium-mediated intracellular signaling}

As described above, working memory performance has been demonstrated to obey an inverted U-shaped response curve as a result of increasing $\mathrm{D}_{1}$ stimulation or dopamine levels. This relationship has been demonstrated not only in experimental animals such as rats and monkeys, but also in human volunteers.

Based on the distribution of $\mathrm{D}_{1}$ receptors on both excitatory and inhibitory neurons, a mechanism for the observed inverted-U dose response curve for dopamine has been proposed.
Goldman-Rakic and colleagues suggested that low concentrations of dopamine activate $\mathrm{D}_{1}$ receptors located on both the prefrontal excitatory and inhibitory neurons. However, at these lower concentrations, $\mathrm{D}_{1}$ stimulation is more effective at enhancing the activity of excitatory neurons, thus facilitating delay cell activity and working memory. In contrast, higher levels of dopamine result in a plateau in the enhancement of excitatory activity, yet still facilitate inhibitory neuron activity. This increased inhibitory activity reduces the persistent activity of excitatory neurons necessary for working memory (Goldman-Rakic et al. 2000).

As an alternative to the mechanism proposed by GoldmanRakic and colleagues, the inverted-U-shaped effect observed as a result of either too much or too little $\mathrm{D}_{1}$ receptor activity may be explained by an independent model that involves a shift from calcium-mediated phosphatase- to kinase-dominated signaling (Fig. 3). As indicated above, calcineurin is activated at low levels of intracellular calcium. At low levels of $D_{1}$ stimulation, $G_{q^{-}}$ mediated calcium release could boost calcineurin activity, thereby improving working memory. On the other hand, at high levels of $\mathrm{D}_{1}$ stimulation, calcium concentrations may rise to levels sufficient to activate calcium-dependent protein kinases (e.g., PKC, CaMKII) and antagonize the substrate dephosphorylation required for working memory. At present, however, it is not known whether this shift occurs in excitatory neurons, inhibitory neurons, or both.

This opposing action of kinase and phosphatase activities on working memory, as a consequence of rising intracellular calcium, may also explain the differential influences of increasing norepinephrine stimulation. High levels of norepinephrine activate $\alpha_{1}$ adrenoreceptors and have been demonstrated to impair working memory (Arnsten and Goldman-Rakic 1985). Activation

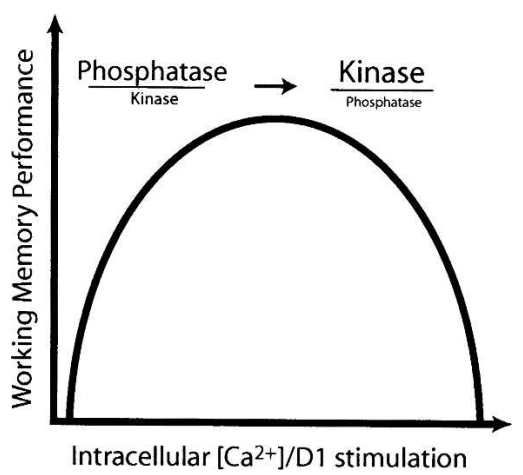

Figure 3. A proposed relationship between intracellular calcium levels, phosphatase-kinase activities, and working memory. The observed inverted-U response curve for working memory in relation to D1 stimulation (red curve) can be explained by activation of calcium-sensitive protein phosphatase activity at low levels of stimulation (required for working memory) and activation of calcium-sensitive protein kinases at high levels of D1 stimulation (impairs working memory). 

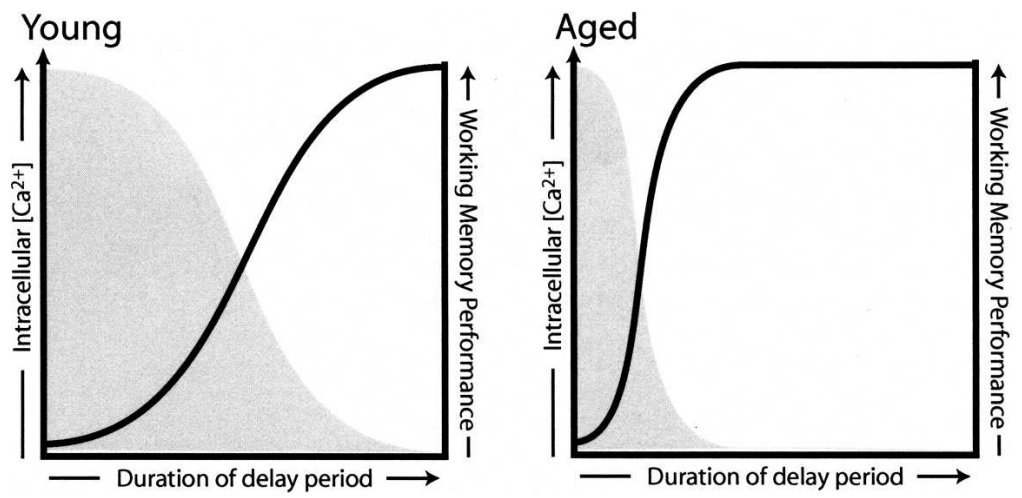

Figure 4. A proposed relationship between altered calcium homeostasis in aged animals and working memory impairments. In young animals, persistent neuronal activity may result in a gradual accumulation of calcium and activation of calcium-sensitive kinases, possibly defining the temporal limits of working memory (left panel, shaded area). In aged animals, increased calcium levels or prolonged decay of calcium signals may hasten the transition from phosphatase-dominated to kinasedominated activities. This accelerated transition may explain the working memory impairments seen in aged animals when tested using long, but not short, delay periods (right panel, shaded area). of these receptors has been linked to PKC activation, and PKC inhibition improves working memory in conditions associated with high norepinephrine levels such as stress (Birnbaum et al. 2004).

The calcium model could also account for the working memory deficits often observed in aged animals and humans. It has been reported that while aged and young rats perform working memory tasks equally well when the delay period is short, the performance of aged animals is significantly impaired in longer delay-period tests (Dunnett et al. 1988). Although it has been consistently demonstrated that calcium homeostasis is perturbed in the neurons of aged animals, the degree and/or direction of change depends on the structure examined and the method of evaluation used. For example, elevated resting levels of neuronal calcium, increased density of L-type calcium channels, and prolonged decay of calcium signals have been reported (Martinez et al. 1988; Giovannelli and Pepeu 1989; Verkhratsky et al. 1994; Villalba et al. 1995; Thibault and Landfield 1996; Toescu and Verkhratsky 2000). These alterations in neuronal calcium homeostasis may yield a shift in the phosphatase-kinase ratio required for proper working memory function (Fig. 4). For instance, in test paradigms with long delay periods, the persistent activity of the delay-period cells may result in an accumulation of calcium and calcium-sensitive kinase activation. As kinase activity appears to negatively influence working memory, their activation would result in poor working memory performance. In contrast, calcium-mediated phosphatase activity may persist long enough to maintain the dephosphorylation of the required targets when the delay periods are short. As shown in Figure 4, the delay periods at which working memory is present may depend on the magnitude of calcium change. For instance, aged animals with higher intracellular calcium (either basal or influx) are predicted to have normal working memory at only very short delay periods. By comparison, aged animals with modest increases in intracellular calcium may have detectable working memory at both the short and intermediate time points.

\section{Short- and long-term vs. working memory}

It is well documented that protein kinases such as CaMKII, PKC, and PKA are required for short- and long-term memory. The use of pharmacological inhibitors or genetic mutations to inactivate these kinases has repeatedly been observed to result in spatial and fear memory deficits (Abeliovich et al. 1993; Mayford et al.
In contrast to the necessary role of PKC and CaMKII activation in short-term memory, the activities of these kinases seem to be detrimental for working memory performance. Likewise, whereas inhibition of calcineurin impairs working memory, it has been shown to facilitate short- and long-term memories. Consistent with the negative role of protein kinase activity, studies have shown that stimulation of PKA activity in the prefrontal cortex impairs working memory (Taylor et al. 1999; Runyan and Dash 2005). For example, it has been shown that age-associated working memory impairments in rats and monkeys are due to over-activation of the cAMP/PKA pathway in the PFC (Ramos et al. 2003). In addition to its influence on PKA activity, elevated cAMP levels have been recently demonstrated to impair working memory by directly interacting with HCN channels (Wang et al. 2007). Taken together, these studies suggest that working and short-term memory require different, and possibly antagonistic, intracellular mechanisms for their manifestation (Fig. 5).

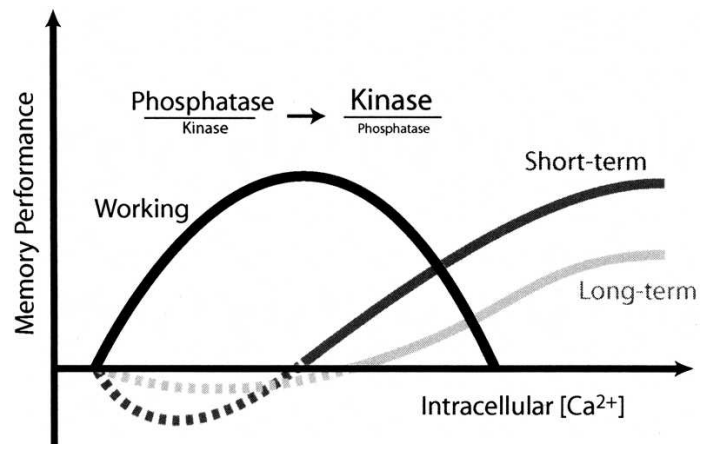

Figure 5. A proposed relationship between intracellular calcium levels, phosphatase-kinase activities, and working, short- and long-term memory. The figure shows the observed inverted- $U$ response curve for working memory in relation to rises in intracellular calcium (black arched curve). Experimental findings show that while calcineurin activity (occurring at low calcium levels) is required for working memory, it impairs short- and long-term memory. The curves shown for short- (dark gray curve) and long-term (light gray curve) memory are reminiscent of those proposed by Bienenstock et al. (1982) for synaptic plasticity. However, it has not been tested whether modest increases in intracellular calcium would impair short- and long-term memories (dashed dark and light gray lines). Since repeated training is often required for long-term memory, the formation of this type of memory may require higher levels of intracellular calcium as compared with short-term memory. 
An antagonistic intracellular mechanism may have functional implications. As described above, working memory involves the transient maintenance of information for subsequent manipulation in order to guide goal-directed behaviors. Once the objective is achieved, there is no need to store this transient information in a longer form. It is therefore possible that using opposing biochemical mechanisms (e.g., kinases are required for long-term memory, but appear to be detrimental to working memory) may ensure that information held in working memory is not stored in more enduring forms. This enables a differentiation of circumstances, in which one forms long-term memories from those circumstances in which one has to merely transiently keep in mind and use particular information momentarily.

\section{Disorders of working memory}

Several types of neurological disorders are marked by deficits in working memory. Since the late 1800 s, initially through studies of brain-injured patients, it has been known that damage to the PFC impairs the individual's ability to make appropriate and directed actions. Subsequent studies have revealed that PFC damage results in deficits in working memory, which can give rise to many of the behavioral abnormalities observed in these earlier studies. These patients are easily distracted, are impaired at focusing and maintaining attention on sensory stimuli, have poor concentration and organization of thought, and are more susceptible to proactive interference (Woods and Knight 1986; Godefroy and Rousseaux 1996; Thompson-Schill et al. 2002). In addition to PFC damage, deficits in working memory are also associated with schizophrenia, ADHD, Alzheimer's disease (AD),
Parkinson's disease (PD), and normal aging. The abnormal working memory exhibited by these patients has been linked to dysfunctional prefrontal neurotransmission. For instance, whereas the positive or psychotic symptoms in schizophrenia are associated with increased dopaminergic transmission in subcortical regions such as the striatum, the cognitive impairments (e.g., impaired working memory) are associated with decreased prefrontal dopaminergic transmission (Weinberger 1987; Davis et al. 1991). Additionally, PET studies in schizophrenics have shown decreased dopamine $\mathrm{D}_{1}$ receptor binding (Okubo et al. 1997, but see Abi-Dargham et al. 2002). Table 2 provides an overview of the cognitive deficits associated with each of these different disorders and aging. The modulatory neurotransmitter systems that participate in normal working memory and have been reported to be altered in each of these conditions are listed.

\section{Treatment considerations for working memory disorders}

Although continued research is required to fully explore the molecular mechanisms underlying the maintenance of neuronal activity required for working memory, the results obtained to date suggest some challenges in the treatment of working memory disorders. As indicated above, it is well known that CaMKII, PKC, and PKA activities are necessary for short- and long-term memory. Activation of these kinases in working memory, however, appears to be detrimental. Thus, strategies aimed at reducing the activity of PKC or CaMK in order to restore working memory may have detrimental effects on short- and long-term

Table 2. Disorders resulting in working memory deficits and the abnormalities in prefrontal neurotransmitters associated with these deficits

\begin{tabular}{|c|c|c|c|}
\hline Disorders & Symptoms/W.M. deficits & Neurotransmitter systems & References \\
\hline $\begin{array}{l}\text { Traumatic Brain Injury } \\
\text { (TBI) }\end{array}$ & $\begin{array}{l}\text { W.M. deficits resemble those following frontal } \\
\text { lobe damage. TBI patients are impaired in } \\
\text { six different W.M. tasks. Etiologies consist of } \\
\text { difficulty in active and effortful planning as } \\
\text { well as in learning and memory recall. }\end{array}$ & $\begin{array}{l}\text { Disregulation of prefrontal } \\
\text { catecholaminergic (DA, NE, and E) } \\
\text { transmission. In particular, prefrontal DA and } \\
\text { NE transmission are altered. DA and NE } \\
\text { reuptake inhibitors improve W.M. A D } 2 \\
\text { agonist has been shown to improve W.M. }\end{array}$ & $\begin{array}{l}\text { For review, see } \\
\text { McAllister et al. } \\
2004\end{array}$ \\
\hline $\begin{array}{l}\text { Attention } \\
\text { Deficit/Hyperactivity } \\
\text { Disorders (ADHD) }\end{array}$ & $\begin{array}{l}\text { Core deficits are poor attention regulation, } \\
\text { impulsivity, and hyperactivity. As these } \\
\text { deficits are antagonistic to the capacity for } \\
\text { W.M., ADHD patients are also impaired in } \\
\text { W.M. }\end{array}$ & $\begin{array}{l}\text { Reduced prefrontal size and activity. Reduced } \\
\text { prefrontal catecholamine input. Links have } \\
\text { been made between ADHD and genes related } \\
\text { to DA and NE. Effective treatments for ADHD } \\
\text { facilitate catecholamine transmission. } \\
\text { Additionally, } \alpha_{2} \text {-adrenoreceptor agonist } \\
\text { improves W.M. in ADHD patients. }\end{array}$ & $\begin{array}{l}\text { For review, see Arnsten } \\
\quad 2006\end{array}$ \\
\hline Schizophrenia & $\begin{array}{l}\text { Includes both positive symptoms (e.g., } \\
\text { hallucinations) and negative symptoms (e.g., } \\
\text { impaired working memory). Several } \\
\text { indicators suggest that many cognitive } \\
\text { dysfunctions associated with schizophrenia } \\
\text { are a result of underlying W.M. deficits. } \\
\text { W.M. is the most consistently observed } \\
\text { deficit in schizophrenia. }\end{array}$ & $\begin{array}{l}\text { W.M. deficits in schizophrenia have been linked } \\
\text { with decreased prefrontal DA transmission; } \\
\text { reduced fluorodopa uptake and cerebral } \\
\text { blood flow to the DLPF; a decrease in } \\
\text { prefrontal } \mathrm{D}_{1} \text { receptor binding during W.M.; } \\
\text { and overactivation of prefrontal } \\
\alpha_{2} \text {-adrenoreceptors. Schizophrenia has also } \\
\text { been linked to prefrontal calcium signaling } \\
\text { dysfunction. }\end{array}$ & $\begin{array}{l}\text { For review, see } \\
\text { Goldman-Rakic et al. } \\
2004\end{array}$ \\
\hline $\begin{array}{l}\text { Alzheimer's Disease } \\
\text { (AD) }\end{array}$ & $\begin{array}{l}\text { Progressive decrements in cognitive } \\
\text { functioning and memory deficiencies. } \\
\text { Evidence suggests that memory deficits in } \\
\text { early } A D \text { result from impaired memory } \\
\text { acquisition. }\end{array}$ & $\begin{array}{l}\text { Reduced acetylcholinergic, serotonergic, and } \\
\text { norepinergic activity in the frontal cortex. } \\
\alpha_{2} \text {-adrenergic receptor agonists improve } \\
\text { W.M. in AD patients. }\end{array}$ & $\begin{array}{l}\text { For review, see Morris } \\
\text { and Baddeley 1988; } \\
\text { Germano and } \\
\text { Kinsella } 2005\end{array}$ \\
\hline $\begin{array}{l}\text { Parkinson's Disease } \\
\quad \text { (PD) }\end{array}$ & $\begin{array}{l}\text { Movement disorder that may result in } \\
\text { cognitive deficits and dementia. PD patients } \\
\text { also have impaired active W.M. and } \\
\text { problems organizing and using new } \\
\text { materials as well as applying strategies. }\end{array}$ & $\begin{array}{l}\text { Disregulated prefrontal activity as a result of a } \\
\text { reduction in subcortical input into the frontal } \\
\text { cortex. Evidence indicates that prefrontal DA } \\
\text { transmission is impaired in PD. }\end{array}$ & $\begin{array}{l}\text { Mattay et al. 2002; } \\
\text { Brooks } 2006\end{array}$ \\
\hline Aging & $\begin{array}{l}\text { Decline in cognitive function. Impaired } \\
\text { working memory. Increased sensitivity to } \\
\text { interference from task- or goal-irrelevant } \\
\text { information. }\end{array}$ & $\begin{array}{l}\text { Deterioration of prefrontal DA signaling. W.M. } \\
\text { is improved with moderate augmentation of } \\
\text { prefrontal } D_{1} \text { receptor activity. Inhibition of } \\
\text { PKA activity improves W.M. in aged monkeys. }\end{array}$ & $\begin{array}{l}\text { For review, see } \\
\text { Williams and Castner } \\
2006\end{array}$ \\
\hline
\end{tabular}


memory. As has been suggested by Arnsten and colleagues regarding the potential negative influences of PKA stimulation on working memory (when utilized as a means of improving longterm memories) (Arnsten et al. 2005), it now appears that global inhibition of calcium-sensitive kinases to improve working memory may have similar complicating influences on long-term memory. However, it has not yet been tested whether the degree of kinase inhibition necessary to improve working memory in pathological situations is sufficient to impair short- or long-term memories. Likewise, strategies to augment phosphatase activity, while potentially improving working memory, may have negative influences on longer lasting forms of memory, depending on the degree of activation. Although yet to be experimentally tested, low doses of drugs such as SKF83959 that have little effect on adenylyl cyclase and PKA activity, but stimulate PLC-coupled $\mathrm{D}_{1}$ receptors (Undie et al. 1994; Jin et al. 2003), may offer a means of treating working memory deficits without overt influences on other cognitive processes. Alternatively, therapies aimed at the specific downstream substrates (e.g., ion channels) that are required for, or impair, working memory may have clinical utility. For example, intra-mPFC infusion of the HCN channel blocker ZD7288 has been demonstrated to enhance spatial working memory in rats (Wang et al. 2007). As research in this area continues, the challenges associated with the treatment of working memory disorders will become defined, and new strategies to overcome these deficits will be revealed.

\section{Acknowledgments}

We thank Drs. James Knierim and Harel Shouval for their invaluable comments on this manuscript. The work performed in our laboratories was made possible by grants from NIH (NS35457, NS049160, MH072933, NS052313).

\section{References}

Aalto, S., Bruck, A., Laine, M., Nagren, K., and Rinne, J.O. 2005. Frontal and temporal dopamine release during working memory and attention tasks in healthy humans: A positron emission tomography study using the high-affinity dopamine D2 receptor ligand [11C]FLB 457. J. Neurosci. 25: 2471-2477.

Abel, T., Nguyen, P.V., Barad, M., Deuel, T.A., Kandel, E.R., and Bourtchouladze, R. 1997a. Genetic demonstration of a role for PKA in the late phase of LTP and in hippocampus-based long-term memory. Cell 88: 615-626.

Abel, T., Nguyen, P.V., Barad, M., Deuel, T.A., Kandel, E.R., and Bourtchouladze, R. 1997b. Genetic demonstration of a role for PKA in the late phase of LTP and in hippocampus-based long-term memory. Cell 88: 615-626.

Abeliovich, A., Paylor, R., Chen, C., Kim, J.J., Wehner, J.M., and Tonegawa, S. 1993. PKC $\gamma$ mutant mice exhibit mild deficits in spatial and contextual learning. Cell 75: 1263-1271.

Abi-Dargham, A., Mawlawi, O., Lombardo, I., Gil, R., Martinez, D., Huang, Y., Hwang, D.R., Keilp, J., Kochan, L., Van Heertum, R., et al. 2002. Prefrontal dopamine D1 receptors and working memory in schizophrenia. J. Neurosci. 22: 3708-3719.

Adlersberg, M., Hsiung, S.C., Glickstein, S.B., Liu, K.P., Tamir, H., and Schmauss, C. 2004. Regulation of dopamine D-receptor activation in vivo by protein phosphatase $2 \mathrm{~B}$ (calcineurin). J. Neurochem. 90: $865-873$

Alagarsamy, S., Saugstad, J., Warren, L., Mansuy, I.M., Gereau, R.W., and Conn, P.J. 2005. NMDA-induced potentiation of mGluR5 is mediated by activation of protein phosphatase $2 \mathrm{~B} /$ calcineurin. Neuropharmacology 49 (Suppl. 1): 135-145.

Arnsten, A.F. 2000. Through the looking glass: Differential noradenergic modulation of prefrontal cortical function. Neural Plast. 7: 133-146.

Arnsten, A.F. 2006. Fundamentals of attention-deficit/hyperactivity disorder: Circuits and pathways. J. Clin. Psychiatry 67 (Suppl. 8): $7-12$.

Arnsten, A.F. and Goldman-Rakic, P.S. 1985. Alpha 2-adrenergic mechanisms in prefrontal cortex associated with cognitive decline in aged nonhuman primates. Science 230: 1273-1276.

Arnsten, A.F. and Goldman-Rakic, P.S. 1998. Noise stress impairs prefrontal cortical cognitive function in monkeys: Evidence for a hyperdopaminergic mechanism. Arch. Gen. Psychiatry 55: 362-368.
Arnsten, A.F., Cai, J.X., Murphy, B.L., and Goldman-Rakic, P.S. 1994. Dopamine D1 receptor mechanisms in the cognitive performance of young adult and aged monkeys. Psychopharmacology 116: 143-151.

Arnsten, A.F., Ramos, B.P., Birnbaum, S.G., and Taylor, J.R. 2005. Protein kinase A as a therapeutic target for memory disorders: Rationale and challenges. Trends Mol. Med. 11: 121-128.

Arthur, J.M., Collinsworth, G.P., Gettys, T.W., and Raymond, J.R. 1999. Agonist-induced translocation of $\mathrm{Gq} / 11 \alpha$ immunoreactivity directly from plasma membrane in MDCK cells. Am. J. Physiol. 276: F528-F534.

Aultman, J.M. and Moghaddam, B. 2001. Distinct contributions of glutamate and dopamine receptors to temporal aspects of rodent working memory using a clinically relevant task. Psychopharmacology 153: $353-364$.

Baddeley, A. 2001. The concept of episodic memory. Philos. Trans. R. Soc. Lond. B Biol. Sci. 356: 1345-1350.

Bienenstock, E.L., Cooper, L.N., and Munro, P.W. 1982. Theory for the development of neuron selectivity: Orientation specificity and binocular interaction in visual cortex. J. Neurosci. 2: 32-48.

Birnbaum, S., Gobeske, K.T., Auerbach, J., Taylor, J.R., and Arnsten, A.F. 1999. A role for norepinephrine in stress-induced cognitive deficits: Alpha-1-adrenoceptor mediation in the prefrontal cortex. Biol. Psychiatry 46: 1266-1274.

Birnbaum, S.G., Yuan, P.X., Wang, M., Vijayraghavan, S., Bloom, A.K., Davis, D.J., Gobeske, K.T., Sweatt, J.D., Manji, H.K., and Arnsten, A.F. 2004. Protein kinase C overactivity impairs prefrontal cortical regulation of working memory. Science 306: 882-884.

Brooks, D.J. 2006. Dopaminergic action beyond its effects on motor function: Imaging studies. J. Neurol. 253 (Suppl. 4): iv8-iv15.

Brozoski, T.J., Brown, R.M., Rosvold, H.E., and Goldman, P.S. 1979. Cognitive deficit caused by regional depletion of dopamine in prefrontal cortex of rhesus monkey. Science 205: 929-932.

Buckner, R.L., Logan, J., Donaldson, D.I., and Wheeler, M.E. 2000. Cognitive neuroscience of episodic memory encoding. Acta Psychol. 105: $127-139$.

Chen, G., Greengard, P., and Yan, Z. 2004. Potentiation of NMDA receptor currents by dopamine D1 receptors in prefrontal cortex. Proc. Natl. Acad. Sci. 101: 2596-2600.

Cools, R. 2006. Dopaminergic modulation of cognitive function-implications for L-DOPA treatment in Parkinson's disease. Neurosci. Biobehav. Rev. 30: 1-23.

D’Esposito, M., Detre, J.A., Alsop, D.C., Shin, R.K., Atlas, S., and Grossman, M. 1995. The neural basis of the central executive system of working memory. Nature 378: 279-281.

Davis, K.L., Kahn, R.S., Ko, G., and Davidson, M. 1991. Dopamine in schizophrenia: A review and reconceptualization. Am. J. Psychiatry 148: $1474-1486$.

Day, M., Olson, P.A., Platzer, J., Striessnig, J., and Surmeier, D.J. 2002. Stimulation of 5-HT(2) receptors in prefrontal pyramidal neurons inhibits $\mathrm{Ca}(\mathrm{v}) 1.2 \mathrm{~L}$ type $\mathrm{Ca}^{2+}$ currents via a PLCß/IP3/calcineurin signaling cascade. J. Neurophysiol. 87: 2490-2504.

de Rooij, J., Zwartkruis, F.J., Verheijen, M.H., Cool, R.H., Nijman, S.M., Wittinghofer, A., and Bos, J.L. 1998. Epac is a Rap1 guanine-nucleotide-exchange factor directly activated by cyclic AMP. Nature 396: 474-477.

Didriksen, M. 1995. Effects of antipsychotics on cognitive behaviour in rats using the delayed non-match to position paradigm. Eur. J. Pharmacol. 281: 241-250.

Dong, Y. and White, F.J. 2003. Dopamine D1-class receptors selectively modulate a slowly inactivating potassium current in rat medial prefrontal cortex pyramidal neurons. J. Neurosci. 23: 2686-2695.

Dudchenko, P.A. 2004. An overview of the tasks used to test working memory in rodents. Neurosci. Biobehav. Rev. 28: 699-709.

Dunnett, S.B., Evenden, J.L., and Iversen, S.D. 1988. Delay-dependent short-term memory deficits in aged rats. Psychopharmacology 96: $174-180$.

Durstewitz, D., Seamans, J.K., and Sejnowski, T.J. 2000. Neurocomputational models of working memory. Nat. Neurosci. 3 (Suppl): 1184-1191.

Egorov, A.V., Hamam, B.N., Fransen, E., Hasselmo, M.E., and Alonso, A.A. 2002. Graded persistent activity in entorhinal cortex neurons. Nature 420: $173-178$.

Franowicz, J.S. and Arnsten, A.F. 1998. The $\alpha$-2a noradrenergic agonist, guanfacine, improves delayed response performance in young adult rhesus monkeys. Psychopharmacology 136: 8-14.

Friedman, J.I., Temporini, H., and Davis, K.L. 1999. Pharmacologic strategies for augmenting cognitive performance in schizophrenia. Biol. Psychiatry 45: 1-16.

Funahashi, S., Chafee, M.V., and Goldman-Rakic, P.S. 1993. Prefrontal neuronal activity in rhesus monkeys performing a delayed anti-saccade task. Nature 365: 753-756.

Fuster, J.M. and Alexander, G.E. 1971. Neuron activity related to 
short-term memory. Science 173: 652-654.

Gao, W.J. and Goldman-Rakic, P.S. 2003. Selective modulation of excitatory and inhibitory microcircuits by dopamine. Proc. Natl. Acad. Sci. 100: 2836-2841.

Gao, W.J. and Goldman-Rakic, P.S. 2006. NMDA receptor-mediated epileptiform persistent activity requires calcium release from intracellular stores in prefrontal neurons. Exp. Neurol. 197: 495-504.

Germano, C. and Kinsella, G.J. 2005. Working memory and learning in early Alzheimer's disease. Neuropsychol. Rev. 15: 1-10.

Giovannelli, L. and Pepeu, G. 1989. Effect of age on $\mathrm{K}^{+}$-induced cytosolic $\mathrm{Ca}^{2+}$ changes in rat cortical synaptosomes. J. Neurochem. 53: $392-398$.

Godefroy, O. and Rousseaux, M. 1996. Divided and focused attention in patients with lesion of the prefrontal cortex. Brain Cogn. 30: $155-174$

Goldman-Rakic, P.S., Muly III, E.C., and Williams, G.V. 2000. D receptors in prefrontal cells and circuits. Brain Res. Brain Res. Rev. 31: $295-301$

Goldman-Rakic, P.S., Castner, S.A., Svensson, T.H., Siever, L.J., and Williams, G.V. 2004. Targeting the dopamine D1 receptor in schizophrenia: Insights for cognitive dysfunction. Psychopharmacology 174: 3-16.

Gonzalez-Burgos, G., Kroener, S., Seamans, J.K., Lewis, D.A., and Barrionuevo, G. 2005. Dopaminergic modulation of short-term synaptic plasticity in fast-spiking interneurons of primate dorsolateral prefrontal cortex. J. Neurophysiol. 94: 4168-4177.

Gorelova, N.A. and Yang, C.R. 2000. Dopamine D1/D5 receptor activation modulates a persistent sodium current in rat prefrontal cortical neurons in vitro. J. Neurophysiol. 84: 75-87.

Gorelova, N., Seamans, J.K., and Yang, C.R. 2002. Mechanisms of dopamine activation of fast-spiking interneurons that exert inhibition in rat prefrontal cortex. J. Neurophysiol. 88: 3150-3166.

Granon, S., Poucet, B., Thinus-Blanc, C., Changeux, J.P., and Vidal, C. 1995. Nicotinic and muscarinic receptors in the rat prefrontal cortex: Differential roles in working memory, response selection and effortful processing. Psychopharmacology 119: 139-144.

Ikegami, S. and Inokuchi, K. 2000. Antisense DNA against calcineurin facilitates memory in contextual fear conditioning by lowering the threshold for hippocampal long-term potentiation induction. Neuroscience 98: 637-646.

Jacobsen, C. 1936. Studies of cerebral function in primates. Comp. Psychol. Monogr. 13: 3-60.

Jentsch, J.D., Olausson, P., Nestler, E.J., and Taylor, J.R. 2002. Stimulation of protein kinase a activity in the rat amygdala enhances reward-related learning. Biol. Psychiatry 52: 111-118.

Jin, L.Q., Goswami, S., Cai, G., Zhen, X., and Friedman, E. 2003. SKF83959 selectively regulates phosphatidylinositol-linked D1 dopamine receptors in rat brain. J. Neurochem. 85: 378-386.

Jonides, J., Smith, E.E., Koeppe, R.A., Awh, E., Minoshima, S., and Mintun, M.A. 1993. Spatial working memory in humans as revealed by PET. Nature 363: 623-625.

Koch, K.W. and Fuster, J.M. 1989. Unit activity in monkey parietal cortex related to haptic perception and temporary memory. Exp. Brain Res. 76: 292-306.

Koh, P.O., Bergson, C., Undie, A.S., Goldman-Rakic, P.S., and Lidow, M.S. 2003. Up-regulation of the D1 dopamine receptor-interacting protein, calcyon, in patients with schizophrenia. Arch. Gen. Psychiatry 60: 311-319.

Kojima, S. and Goldman-Rakic, P.S. 1984. Functional analysis of spatially discriminative neurons in prefrontal cortex of rhesus monkey. Brain Res. 291: 229-240.

Kolb, B. 1984. Functions of the frontal cortex of the rat: A comparative review. Brain Res. 320: 65-98.

Lee, A.C., Robbins, T.W., and Owen, A.M. 2000. Episodic memory meets working memory in the frontal lobe: Functional neuroimaging studies of encoding and retrieval. Crit. Rev. Neurobiol. 14: 165-197.

Li, B.M. and Mei, Z.T. 1994. Delayed-response deficit induced by local injection of the $\alpha 2$-adrenergic antagonist yohimbine into the dorsolateral prefrontal cortex in young adult monkeys. Behav. Neural Biol. 62: 134-139.

Lidow, M.S. 2003. Calcium signaling dysfunction in schizophrenia: A unifying approach. Brain Res. Brain Res. Rev. 43: 70-84.

Lidow, M.S., Goldman-Rakic, P.S., Gallager, D.W., and Rakic, P. 1991. Distribution of dopaminergic receptors in the primate cerebral cortex: Quantitative autoradiographic analysis using $\left[{ }^{3} \mathrm{H}\right]$ raclopride, $\left[{ }^{3} \mathrm{H}\right]$ spiperone and $\left[{ }^{3} \mathrm{H}\right] \mathrm{SCH} 23390$. Neuroscience 40: 657-671.

Malinow, R., Schulman, H., and Tsien, R.W. 1989. Inhibition of postsynaptic PKC or CaMKII blocks induction but not expression of LTP. Science 245: 862-866.

Malleret, G., Haditsch, U., Genoux, D., Jones, M.W., Bliss, T.V., Vanhoose, A.M., Weitlauf, C., Kandel, E.R., Winder, D.G., and Mansuy, I.M. 2001. Inducible and reversible enhancement of learning, memory, and long-term potentiation by genetic inhibition of calcineurin. Cell 104: 675-686.

Mao, Z.M., Arnsten, A.F., and Li, B.M. 1999. Local infusion of an $\alpha-1$ adrenergic agonist into the prefrontal cortex impairs spatial working memory performance in monkeys. Biol. Psychiatry 46: 1259-1265.

Martinez, A., Vitorica, J., and Satrustegui, J. 1988. Cytosolic free calcium levels increase with age in rat brain synaptosomes. Neurosci. Lett. 88: $336-342$.

Mattay, V.S., Tessitore, A., Callicott, J.H., Bertolino, A., Goldberg, T.E., Chase, T.N., Hyde, T.M., and Weinberger, D.R. 2002. Dopaminergic modulation of cortical function in patients with Parkinson's disease. Ann. Neurol. 51: 156-164.

Maurice, N., Tkatch, T., Meisler, M., Sprunger, L.K., and Surmeier, D.J. 2001. D1/D5 dopamine receptor activation differentially modulates rapidly inactivating and persistent sodium currents in prefrontal cortex pyramidal neurons. J. Neurosci. 21: 2268-2277.

Mayford, M., Bach, M.E., Huang, Y.Y., Wang, L., Hawkins, R.D., and Kandel, E.R. 1996. Control of memory formation through regulated expression of a CaMKII transgene. Science 274: 1678-1683.

McAllister, T.W., Flashman, L.A., Sparling, M.B., and Saykin, A.J. 2004. Working memory deficits after traumatic brain injury: Catecholaminergic mechanisms and prospects for treatment-A review. Brain Inj. 18: 331-350.

McGlade-McCulloh, E., Yamamoto, H., Tan, S.E., Brickey, D.A., and Soderling, T.R. 1993. Phosphorylation and regulation of glutamate receptors by calcium/calmodulin-dependent protein kinase II. Nature 362: 640-642.

Meador-Woodruff, J.H., Damask, S.P., Wang, J., Haroutunian, V., Davis, K.L., and Watson, S.J. 1996. Dopamine receptor mRNA expression in human striatum and neocortex. Neuropsychopharmacology 15: 17-29.

Miller, E.K., Li, L., and Desimone, R. 1993. Activity of neurons in anterior inferior temporal cortex during a short-term memory task. $J$. Neurosci. 13: 1460-1478.

Mirnics, K., Middleton, F.A., Stanwood, G.D., Lewis, D.A., and Levitt, P. 2001. Disease-specific changes in regulator of G-protein signaling 4 (RGS4) expression in schizophrenia. Mol. Psychiatry 6: 293-301.

Misonou, H., Mohapatra, D.P., Park, E.W., Leung, V., Zhen, D., Misonou, K., Anderson, A.E., and Trimmer, J.S. 2004. Regulation of ion channel localization and phosphorylation by neuronal activity. Nat. Neurosci. 7: 711-718.

Morris, R.G. and Baddeley, A.D. 1988. Primary and working memory functioning in Alzheimer-type dementia. J. Clin. Exp. Neuropsychol. 10: $279-296$.

Muly III, E.C., Szigeti, K., and Goldman-Rakic, P.S. 1998. D1 receptor in interneurons of macaque prefrontal cortex: distribution and subcellular localization. J. Neurosci. 18: 10553-10565.

Norris, C.M., Blalock, E.M., Chen, K.C., Porter, N.M., and Landfield, P.W. 2002. Calcineurin enhances L-type $\mathrm{Ca}(2+)$ channel activity in hippocampal neurons: Increased effect with age in culture. Neuroscience 110: 213-225.

Okubo, Y., Suhara, T., Suzuki, K., Kobayashi, K., Inoue, O., Terasaki, O., Someya, Y., Sassa, T., Sudo, Y., Matsushima, E., et al. 1997. Decreased prefrontal dopamine D1 receptors in schizophrenia revealed by PET. Nature 385: 634-636.

Paspalas, C.D. and Goldman-Rakic, P.S. 2004. Microdomains for dopamine volume neurotransmission in primate prefrontal cortex. $J$. Neurosci. 24: 5292-5300.

Petrides, M., Alivisatos, B., Meyer, E., and Evans, A.C. 1993. Functiona activation of the human frontal cortex during the performance of verbal working memory tasks. Proc. Natl. Acad. Sci. 90: 878-882.

Phillips, A.G., Ahn, S., and Floresco, S.B. 2004. Magnitude of dopamine release in medial prefrontal cortex predicts accuracy of memory on a delayed response task. J. Neurosci. 24: 547-553.

Ramos, B.P., Birnbaum, S.G., Lindenmayer, I., Newton, S.S., Duman, R.S., and Arnsten, A.F. 2003. Dysregulation of protein kinase a signaling in the aged prefrontal cortex: New strategy for treating age-related cognitive decline. Neuron 40: 835-845.

Ranganath, C., Cohen, M.X., and Brozinsky, C.J. 2005. Working memory maintenance contributes to long-term memory formation: Neural and behavioral evidence. J. Cogn. Neurosci. 17: 994-1010.

Rao, S.G., Williams, G.V., and Goldman-Rakic, P.S. 2000. Destruction and creation of spatial tuning by disinhibition: $\mathrm{GABA}_{\mathrm{A}}$ blockade of prefrontal cortical neurons engaged by working memory. J. Neurosci. 20: $485-494$.

Roeper, J., Lorra, C., and Pongs, O. 1997. Frequency-dependent inactivation of mammalian A-type $\mathrm{K}^{+}$channel KV1.4 regulated by $\mathrm{Ca}^{2+} /$ calmodulin-dependent protein kinase. J. Neurosci. 17: 3379-3391.

Runyan, J.D. and Dash, P.K. 2005. Distinct prefrontal molecular mechanisms for information storage lasting seconds versus minutes. Learn. Mem. 12: 232-238.

Runyan, J.D., Moore, A.N., and Dash, P.K. 2005. A role for prefrontal 
calcium-sensitive protein phosphatase and kinase activities in working memory. Learn. Mem. 12: 103-110.

Russell, V., Allie, S., and Wiggins, T. 2000. Increased noradrenergic activity in prefrontal cortex slices of an animal model for attention-deficit hyperactivity disorder-The spontaneously hypertensive rat. Behav. Brain Res. 117: 69-74.

Sakurai, Y. 1990. Cells in the rat auditory system have sensory-delay correlates during the performance of an auditory working memory task. Behav. Neurosci. 104: $856-868$.

Sandrini, M., Cappa, S.F., Rossi, S., Rossini, P.M., and Miniussi, C. 2003. The role of prefrontal cortex in verbal episodic memory: rTMS evidence. J. Cogn. Neurosci. 15: 855-861.

Sawaguchi, T. 2001. The effects of dopamine and its antagonists on directional delay-period activity of prefrontal neurons in monkeys during an oculomotor delayed-response task. Neurosci. Res. 41: $115-128$.

Sawaguchi, T. and Goldman-Rakic, P.S. 1991. D1 dopamine receptors in prefrontal cortex: Involvement in working memory. Science 251: $947-950$.

Schafe, G.E. and LeDoux, J.E. 2000. Memory consolidation of auditory pavlovian fear conditioning requires protein synthesis and protein kinase A in the amygdala. J. Neurosci. 20: RC96.

Silva, A.J., Paylor, R., Wehner, J.M., and Tonegawa, S. 1992a. Impaired spatial learning in $\alpha$-calcium-calmodulin kinase II mutant mice. Science 257: 206-211.

Silva, A.J., Stevens, C.F., Tonegawa, S., and Wang, Y. 1992b. Deficient hippocampal long-term potentiation in $\alpha$-calcium-calmodulin kinase II mutant mice. Science 257: 201-206.

Simon, H., Scatton, B., and Le Moal, M. 1979. Definitive disruption of spatial delayed alternation in rats after lesions in the ventral mesencephalic tegmentum. Neurosci. Lett. 15: 319-324.

Skeberdis, V.A., Chevaleyre, V., Lau, C.G., Goldberg, J.H., Pettit, D.L., Suadicani, S.O., Lin, Y., Bennett, M.V., Yuste, R., Castillo, P.E., et al 2006. Protein kinase A regulates calcium permeability of NMDA receptors. Nat. Neurosci. 9: 501-510.

Smiley, J.F. and Goldman-Rakic, P.S. 1993. Heterogeneous targets of dopamine synapses in monkey prefrontal cortex demonstrated by serial section electron microscopy: A laminar analysis using the silver-enhanced diaminobenzidine sulfide (SEDS) immunolabeling technique. Cereb. Cortex 3: 223-238.

Solem, M., McMahon, T., and Messing, R.O. 1997. Protein kinase A regulates regulates inhibition of $\mathrm{N}$ - and $\mathrm{P} / \mathrm{Q}$-type calcium channels by ethanol in PC12 cells. J. Pharmacol. Exp. Ther. 282: 1487-1495.

Takashima, A., Jensen, O., Oostenveld, R., Maris, E., van de Coevering, M., and Fernandez, G. 2006. Successful declarative memory formation is associated with ongoing activity during encoding in a distributed neocortical network related to working memory: A magnetoencephalography study. Neuroscience 139: 291-297.

Taylor, J.R., Birnbaum, S., Ubriani, R., and Arnsten, A.F. 1999. Activation of cAMP-dependent protein kinase A in prefrontal cortex impairs working memory performance. J. Neurosci. 19: RC23.

Thibault, O. and Landfield, P.W. 1996. Increase in single L-type calcium channels in hippocampal neurons during aging. Science 272: $1017-1020$

Thompson-Schill, S.L., Jonides, J., Marshuetz, C., Smith, E.E., D'Esposito, M., Kan, I.P., Knight, R.T., and Swick, D. 2002. Effects of frontal lobe damage on interference effects in working memory. Cogn. Affect. Behav. Neurosci. 2: 109-120.

Toescu, E.C. and Verkhratsky, A. 2000. Parameters of calcium homeostasis in normal neuronal ageing. J. Anat. 197: 563-569.

Trantham-Davidson, H., Neely, L.C., Lavin, A., and Seamans, J.K. 2004. Mechanisms underlying differential D1 versus D2 dopamine receptor regulation of inhibition in prefrontal cortex. J. Neurosci. 24: $10652-10659$.

Undie, A.S., Weinstock, J., Sarau, H.M., and Friedman, E. 1994. Evidence for a distinct D1-like dopamine receptor that couples to activation of phosphoinositide metabolism in brain. J. Neurochem. 62: 2045-2048.
Uylings, H.B. and van Eden, C.G. 1990. Qualitative and quantitative comparison of the prefrontal cortex in rat and in primates, including humans. Prog. Brain Res. 85: 31-62.

Verkhratsky, A., Shmigol, A., Kirischuk, S., Pronchuk, N., and Kostyuk, P. 1994. Age-dependent changes in calcium currents and calcium homeostasis in mammalian neurons. Ann. N. Y. Acad. Sci. 747: 365-381.

Villalba, M., Pereira, R., Martinez-Serrano, A., and Satrustegui, J. 1995. Altered cell calcium regulation in synaptosomes and brain cells of the 30-month-old rat: Prominent effects in hippocampus. Neurobiol. Aging 16: 809-816.

Wang, J. and O'Donnell, P. 2001. $\mathrm{D}_{1}$ dopamine receptors potentiate nmda-mediated excitability increase in layer $\mathrm{V}$ prefrontal cortical pyramidal neurons. Cereb. Cortex 11: 452-462.

Wang, H.Y., Undie, A.S., and Friedman, E. 1995. Evidence for the coupling of Gq protein to D1-like dopamine sites in rat striatum: Possible role in dopamine-mediated inositol phosphate formation. Mol. Pharmacol. 48: 988-994.

Wang, M., Ramos, B.P., Paspalas, C.D., Shu, Y., Simen, A., Duque, A., Vijayraghavan, S., Brennan, A., Dudley, A., Nou, E., et al. 2007. $\alpha 2 \mathrm{~A}$-adrenoceptors strengthen working memory networks by inhibiting cAMP-HCN channel signaling in prefrontal cortex. Cell 129: $397-410$

Watanabe, T. and Niki, H. 1985. Hippocampal unit activity and delayed response in the monkey. Brain Res. 325: 241-254.

Weinberger, D.R. 1987. Implications of normal brain development for the pathogenesis of schizophrenia. Arch. Gen. Psychiatry 44: 660-669.

Williams, G.V and Castner, S.A. 2006. Under the curve: Critical issues for elucidating D1 receptor function in working memory. Neuroscience 139: 263-276.

Williams, S.M. and Goldman-Rakic, P.S. 1993. Characterization of the dopaminergic innervation of the primate frontal cortex using a dopamine-specific antibody. Cereb. Cortex 3: 199-222.

Williams, G.V. and Goldman-Rakic, P.S. 1995. Modulation of memory fields by dopamine D1 receptors in prefrontal cortex. Nature 376: $572-575$.

Williams, G.V., Rao, S.G., and Goldman-Rakic, P.S. 2002. The physiological role of 5-HT2A receptors in working memory. $J$. Neurosci. 22: 2843-2854.

Woods, D.L. and Knight, R.T. 1986. Electrophysiologic evidence of increased distractibility after dorsolateral prefrontal lesions. Neurology 36: $212-216$.

Yang, H.C. and Lee, E.H. 1993. Protein kinase C activation facilitates memory retention in rats. Chin. J. Physiol. 36: 115-123.

Young, C.E. and Yang, C.R. 2004. Dopamine D1/D5 receptor modulates state-dependent switching of soma-dendritic $\mathrm{Ca} 2+$ potentials via differential protein kinase $\mathrm{A}$ and $\mathrm{C}$ activation in rat prefrontal cortical neurons. J. Neurosci. 24: 8-23.

Zahrt, J., Taylor, J.R., Mathew, R.G., and Arnsten, A.F. 1997. Supranormal stimulation of D1 dopamine receptors in the rodent prefrontal cortex impairs spatial working memory performance. $J$. Neurosci. 17: 8528-8535.

Zeng, H., Chattarii, S., Barbarosie, M., Rondi-Reig, L., Philpot, B.D., Miyakawa, T., Bear, M.F., and Tonegawa, S. 2001. Forebrain-specific calcineurin knockout selectively impairs bidirectional synaptic plasticity and working/episodic-like memory. Cell 107: 617-629.

Zhang, K., Grady, C.J., Tsapakis, E.M., Andersen, S.L., Tarazi, F.I., and Baldessarini, R.J. 2004. Regulation of working memory by dopamine D4 receptor in rats. Neuropsychopharmacology 29: 1648-1655.

Zhou, Y.D. and Fuster, J.M. 1997. Neuronal activity of somatosensory cortex in a cross-modal (visuo-haptic) memory task. Exp. Brain Res. 116: $551-555$

Received February 16, 2007; accepted in revised form June 7, 2007. 


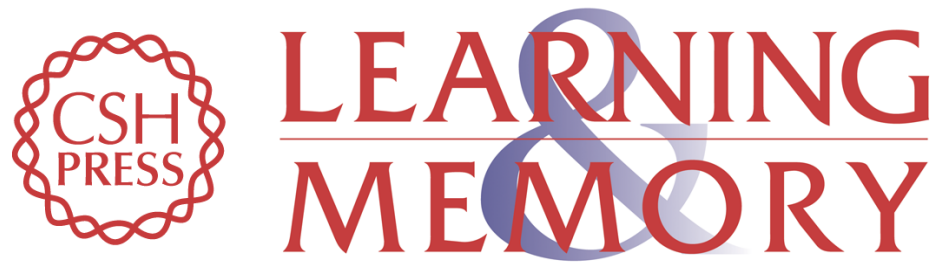

\section{Molecular activity underlying working memory}

Pramod K. Dash, Anthony N. Moore, Nobuhide Kobori, et al.

Learn. Mem. 2007, 14:

Access the most recent version at doi:10.1101//m.558707

References This article cites 126 articles, 35 of which can be accessed free at: http://learnmem.cshlp.org/content/14/8/554.full.html\#ref-list-1

License

Email Alerting Receive free email alerts when new articles cite this article - sign up in the box at the Service top right corner of the article or click here. 